\title{
PENDIDIKAN INDONESIA: \\ DARI HEGEMONI DAN KUASA PENGETAHUAN KE PENDANGKALAN KEMANUSIAAN
}

\author{
Iskandar Zulkarnain, S.IP., M.A*
}

\begin{abstract}
This article discusses about hegemony and knowledge power (the authorities) which created less humanization in Indonesian education. This study uses IPS (social studies subject matter) as the object of the study. The result of the study shows three causes of less humanization in social sciences (IPS), namely: the first, the historical background of Indonesia is full of political and in doctrinal nuance. So the orientation of Indonesian education is automatically reduced for the authority's interests. Second, the implementation of IPS teaching learning model is not flexible. It is monotones and homogeny. It is creates less critical thinking among students. The thirst, there was a symbolical violence in our education because of authorities superiority (teachers, schools) on students.
\end{abstract}

\section{Key Words:}

Education, Hegemony, and Dehumanization

\section{PENDAHULUAN}

Dunia pendidikan Indonesia pascareformasi kian menarik diperbincangkan. Menarik lantaran terjadi fenomena kegagalan pengajaran dan kesalahan pendekatan guru secara kolektif terhadap siswanya di seantero tanah air yang berimplikasi pada tidak tercapainya tujuan pendidikan yang sangat mulia: pembebasan diri dari segala bentuk dehumanisme. Betapa tidak, pola pengajaran yang bersifat indoktrinasi, kaku, dan linier menyebabkan siswa sebagai obyek yang tersubordinasi dari kekuasaan superioritas guru. Praktis, daya kritis dan kreativitas siswa mengalami kejumudan dan mewarnai nuansa pendidikan negeri ini.

Ironinya, pendekatan paradigma tradisional yang bersifat indoktrinasi itu

* Penulis adalah Dosen pada Jurusan Sosiologi, Fakultas Ilmu Sosial dan Ilmu Politik, Universitas Bangka Belitung. telah dijadikan "habitus" guru sehingga menambah runyam dunia pendidikan. Paradigma lama yang mempersempit ruang kebebasan berekspresi siswa melalui pengkotak-kotakan siswa berdasarkan kemampuan hafalan materi (kognitif) semata, menempatkan siswa sebagai kelas inferior yang harus diisi dan dipenuhi dengan ragam pengetahuan. Sementara di sisi lain, aspek afektif dan psikomotorik siswa kian terabaikan. Di sini, pendidikan kita telah mengalami pendangkalan kemanusiaan. Permasalahan yang perlu dikritisi selanjutnya adalah apa yang menyebabkan terjadinya pendangkalan kemanusiaan dan mengapa itu terjadi?

\section{PEMBAHASAN \\ 2.1 Dehumanisasi Pendidikan}

Dehumanisasi dalam pandangan Paulo Freire (2002) adalah suatu bentuk ungkapan nyata yang menunjukkan 
terjadinya proses alienasi dan dominasi. Proses alienasi terjadi berbarengan dengan dominasi sebuah struktur kekuasaan atas suatu obyek dengan tujuan melanggengkan status quo atau mengubah dunia secara radikal. Dalam konteks pendidikan, dehumanisasi pendidikan di mana dominasi struktur kekuasaan lebih kuat ketimbang obyek yang didominasi (sekolah, guru, siswa) tidak menghasilkan dimensi humanistik melainkan dimensi penindasan. Pihak sekolah, guru, dan siswa tidak diakomodisasi haknya dalam menerapkan pendidikan yang humanis.

Secara faktual dehumanisasi pendidikan nyata terjadi. Hal ini dapat dilihat dari tujuan pendidikan yang harus membebaskan dari nilai-nilai kekerasan, indoktrinasi, feodalisme, dan sikap-sikap yang tidak demokratis yang mengkungkung kesadaran siswa tanpa kungkungan struktur kekuasaan apa pun. Kenyataannya, pendidikan kita saat ini masih menempatkan siswa sebagai tabung kosong yang harus diisi dengan ragam pengetahuan dan menganggap mereka sebagai obyek yang bodoh alias tidak tahu apa-apa, sementara guru dianggap sebagai subyek yang serba tahu segala pengetahuan dan informasi. Dengan kata lain, pendidikan kita benar-benar tidak berorientasi pada siswa sentris. Ini dibuktikan dengan paradigma pendidikan yang masih sentralistik, monolog, dan kaku. Di sini, disadari atau tidak, terjadi suatu upaya penerapan pola pendidikan "gaya bank" (istilah Paulo Freire) yang mengesampingkan kemampuan dan peran siswa dalam realitas pendidikan. Inti dari pendidikan "gaya bank" adalah menerapkan proses dehumanisasi yang terjadi dalam dunia pendidikan. Model pendidikan seperti ini telah mengabaikan nalar kritis dan partisipasi siswa dalam proses menuju perubahan.

Selain pendidikan "gaya bank" dehumanisasi pendidikan juga menjelma dalam bentuk kekerasan simbolis. Kekerasan simbolis dalam perspektif Pierre Bourdieu (Jenkins, 2004) adalah setiap tindakan pedagogis yang bertujuan untuk mereproduksi kebudayaan, memaksa sistem simbolisme dan suatu makna terhadap kelompok atau kelas sedemikian rupa, sehingga hal itu dialami sebagai sesuatu yang sah. Artinya, kekuatan kekerasan (struktural, sistematis) yang mereproduksi kebudayaan termasuk pendidikan berasal dari hubungan kekuasaan yang dominan yang bersembunyi di balik kekuatan pedagogis. Tujuan dari reproduksi kebudayaan dan pemaksaan simbolisme/makna tersebut tak lain adalah dalam usaha mendapatkan legitimasi untuk meneguhkan relasi kekuasaan yang memungkinkan keberhasilan nilai-nilai lewat pemaksaan yang tersistematis. Inti penggunaan kekerasan simbolis adalah tindakan pedagogis yang terjadi ketika suatu kekuasaan mereproduksi kebudayaan dalam segala kekurangannya sekaligus mereproduksi relasi kekuasaan yang itu menjamin keberlangsungan dominasi tersebut.

Dalam ranah praksis terdapat tiga mode kekerasan simbolis dalam tindakan pedagogis. Pertama, melalui pendidikan yang tersebar luas (diffuse education), ini terjadi dalam interaksi dengan anggota bangunan sosial. Kedua, pendidikan keluarga, yang itu berbicara untuk dirinya sendiri. Ketiga, pendidikan institusional, yang terjadi dalam lingkungan institusi pendidikan seperti sekolah dan instansi lainnya. Melalui tiga mode inilah kekerasan simbolis menjelma menjadi sebuah 
kekuatan simbolis agen pendidikan yang berkapasitas mendoktrinasi makna pendidikan itu secara sepihak.

Dalam dunia pendidikan di tanah air sistem pedagogisme sangat dominan. Pedagogisme menjelma dalam bentukbentuk yang beragam antara lain melalui kurikulum pendidikan. Kurikulum dalam perspektif pemegang kekuasaan kerap ditafsirkan sebagai sumber-sumber kekuasaan. Maksudnya, kurikulum adalah pertarungan antar-kekuasaan yang hidup dalam suatu masyarakat dalam dunia pendidikan yang heterogen. Pada ranah ini, kelompok masyarakat yang dominan akan mempertahankan kurikulum untuk mempertahankan dominasinya melalui sistem persekolahan. Di sinilah kekerasan simbolis menemukan tempatnya.

\subsection{Pendidikan dan Konstruksi Sejarah}

Persoalan dehumanisasi pendidikan dan kekerasan simbolis yang terdapat pada kurikulum pendidikan kita misalnya pada pelajaran IPS beserta variannya; sejarah, ekonomi, geografi, sosiologi, dan PKn, diakui atau tidak, tentu tidak terlepas dari konteks sejarah yang melatarbelakanginya.

Sejarah Orde Lama sebagaimana meminjam ungkapan H.A.R. Tilaar (2000), telah menempatkan pendidikan sebagai ranah yang terkesampingkan dan menjadikannya arena yang teralienasi dari realitas sosialnya. Hal ini ditunjukkan oleh tujuan pendidikan pada rezim Orde Lama yang tidak terlepas dari politik yang berorientasi kepentingan kekuasaan dan sarana indoktrinasi. Semangat nasionalisme dan rasa persatuan dikonstruksi sebagai realitas bersifat chaufinisme, ditafsirkan secara sempit semata-mata demi kepentingan kekuasaan. Doktrin pendidikan yang menolak segala sesuatu dari luar telah menjauhkan masyarakat dari kebebasan dan kesejahteraan hidup. Di titik ini, pendidikan tidak lagi dimaknai sebagai usaha mengubah realitas sosial menuju praksis, tapi menciptakan keberpihakan pada blok kekuasaan: kapitalisme dan komunisme.

Dalam konteks sejarah Orde Baru pendidikan kian teralienasi. Pendidikan dijadikan alat dominasi dan hegemoni penguasa yang represif dan otoriter. Ada tiga tujuan pendidikan pada rezim Orde Baru, yaitu: pertama, pendidikan sebagai alat penyeragaman. Politik dominasi penguasa Orde Baru menciptakan keseragaman berpikir dan bertindak, sehingga rakyat tidak menemukan kebebasan untuk menentukan jalan sendiri dalam sistem interaksi sosial dan budaya di kehidupannya. Terciptanya masyarakat yang homogen tersebut telah mematikan kehidupan demokrasi di negeri ini. Persoalan kemanusiaan pun menjadi runyam. Kedua, manipulasi pendidikan ekonomi. Tak ada yang menyangkal bahwa ekonomi adalah basis kekuatan Orde Baru. Pertumbuhan ekonomi yang pesat ditandai dengan pembangunan di segala sektor menjadi modal sosial penguasa Orde Baru dalam membuat kebijakan. Namun, modal sosial tersebut telah meruntuhkan struktur ekonomi kerakyatan dengan keberpihakan kepada kapitalisme global. Kesenjangan ekonomi pun menganga lebar.

Kehidupan ekonomi yang menindas rakyat melahirkan sistem pendidikan yang tidak kompetitif dan memunculkan akuntabilitas sosial di masyarakat. Kapitalisme global menguasai produk dalam negeri menyebabkan ketergantungan dan rapuhnya daya saing, serta akuntabilitas sosial sehingga melahirkan sistem kekuasaan yang korup. Sistem ini menjalar 
ke segala sendi kehidupan rakyat dari pusat hingga pinggiran. Ketiga, pendidikan sebagai sarana mengkebiri ke-bhinneka-an. Politik Orde Baru menjadikan heterogenitas sebagai alat pertukaran semu demi melanggengkan kepercayaan publik. Akibatnya, toleransi antar sesama kian luntur, bukan semakin menguat. Budaya konflik dan kekerasan semakin mengemuka baik berbasis individu maupun komunal. Alhasil, pendidikan multikultural kian jauh dari substansinya dan beralih pada menguatnya primordialisme suatu kelompok. Praktis, bangunan kesadaran akan keragaman, toleransi, dan pluralisme kualitatif-pun runtuh

Upaya penguasa Orde Baru memperkuat hegemoni kekuasaannya pada ranah pendidikan semakin menguat dengan menjadikan kurikulum dan metode pengajaran IPS sebagai alat legitimasi kekuasaan. Dari sisi kurikulum, indoktrinasi penguasa Orde Baru sangat kentara. Pendidikan demokrasi, pluralisme, dan multikultural dalam pelajaran PKn (dulu PMP) tidak berkembang, bahkan dijadikan sarana yang bersifat hegemonik. Pendidikan sejarah telah direduksi untuk kepentingan penguasa Orde Baru yang memanipulasi kebenaran sejarah. Pelajaran ekonomi telah dipisahkan dari pendidikan tentang kejujuran, kerja keras, dan pemerataan sosial serta berubah menjadi doktrin pembangunan yang bernuansa kolusi, korupsi, dan nepotisme. Politisasi dan indoktrinasi kurikulum dan metode pengajaran IPS telah menempatkan siswa sebagai subyek yang anti-realitas dan semakin menjauhkan substansi IPS dari nilai-nilai demokrasi, pluralisme, toleransi, civil society, dan hak asasi manusia. Persoalan pendangkalan kemanusiaan pun kian melesat tak terbendung.
Dari hal di atas terlihat bahwa pelajaran IPS — dari segi kurikulum dan metode pengajaran — pada masa lalu telah menumpulkan daya kritis, kreativitas, kemandirian, dan nalar demokrasi siswa sebagai generasi bangsa. Dalam konteks ini, anak didik kita telah dihilangkan dari faktor sosialnya dan yang hanya tersisa hanyalah kekosongan belaka. Akibatnya anak didik kita mengalami amnesia kolektif terhadap realitas masyarakat yang demokratis, pluralis, dan menjunjung tinggi HAM, dan tumbuh menjadi generasi yang melanggengkan perilaku dehumanisasi.

\subsection{Hegemoni dan Kuasa \\ Pengetahuan}

Sejarah pendidikan masa lalu yang kental dengan nuansa politis dan indoktrinasi terus berlanjut hingga ke era Reformasi saat ini. Meskipun di satu sisi kurikulum dan metode pengajaran IPS mengalami reformasi menuju perbaikan secara sistematis, namun di sisi lain nuansa dehumanisasi (pendangkalan kemanusiaan) itu tetap kentara. Dari mana itu diketahui? Ada dua faktor yang menunjukkan terjadinya persoalan dehumanisasi yang menggelinding ke arah pendangkalan kemanusiaan pada ilmu sosial. Pertama, kesalahan konsep pendidikan ilmu sosial kita saat ini. Konsep pendidikan ilmu sosial saat ini mengalami gejala penyempitan makna atas suatu realitas sosial. Misalnya konsep PKn dalam hal demokrasi dan multikulturalisme. Demokrasi seringkali dimaknai dengan arti yang sempit yakni sebagai mekanisme sosial politik yang mengarahkan siswa untuk membangun kesadaran akan hak dan kewajibannya saja. Sementara pemaknaan demokrasi dalam arti luas sebagaimana dikatakan John Dewey seperti dikutip A. Ubaidillah 
(www.kompas.com), lebih sebagai pola hidup bersama dan menekankan kepentingan orang banyak di atas kepentingan pribadi semakin kabur. Ide demokrasi dalam arti luas inilah yang mengalami penyempitan makna sehingga antara demokrasi dan multikulturalisme seakan-akan terpisah.

Dalam konsep pelajaran sejarah, diakui atau tidak, siswa hanya diformat untuk menghafal nama-nama pahlawan dan tokoh-tokoh ternama nasional maupun internasional, atau hanya sekedar tahu harihari besar yang bersejarah tanpa berusaha menyelam ke lauatan sejarah lebih dalam, sehingga konsep sejarah kehilangan ruhnya yang membebaskan. Secara tidak langsung pola pembelajaran sejarah yang tidak kreatif dan kaku telah membuat konsep sejarah itu sendiri hilang dari nuansanya yang reflektif, berkarakter, bersifat perbandingan, dan dialogis.

Serupa dengan konsep sosiologi. Konsep sosiologi tidak semakin membuat siswa dekat dengan berbagai persoalan di masyarakat, tapi sebaliknya menjauhkan mereka dari realitas sosial itu sendiri. Misalnya, siswa kurang menyentuh persoalan interaksi sosial, di mana siswa mampu memahami dan memecahkan ragam persoalan kehidupannya di masyarakat seperti bagaimana siswa berinteraksi dengan orang tua, kerabat, tetangga, teman, dan memecahkan persoalan-persoalan sosial lainnya.

Konsep ilmu sosial yang membuat ia tercabut dari akar sosialnya tentu berimplikasi pada kesalahan materi, metode, evaluasi akhir, dan orientasi pendidikan. Materi ilmu sosial seperti PKn, sejarah, sosiologi dan ekonomi dianggap masih bernuansa Orde Baru yang cenderung militeristis dan indoktrinasi. Tak jauh berbeda dengan metode pengajaran ilmu sosial di mana cara-cara indoktrinasi sering terjadi. Guru seringkali mengibaratkan siswa seperti gelas kosong yang siap diisi dengan air, informasi, doktrin, dan lain-lain yang itu diklaim sebagai kebenaran tunggal. Artinya, ruang dialog dan dialektika siswa untuk menawarkan alternatif lain yang muncul dari gagasan kreatif dan mandiri menjadi tertutup.

Kondisi ini berimbas pula pada kesalahan dalam menentukan bentuk evaluasi pembelajaran. Evaluasi pembelajaran IPS sekarang ini cenderung bersifat kuantitatif, di mana guru lebih menekankan pada nilai-nilai kognitif siswa berdasarkan angka-angka yang tertera dalam raport atau hasil ujian. Atau berkiblat pada standar kelulusan siswa seperti SLTP dalam Ujian Nasional (UN), meski IPS (Ilmu Pengetahuan Sosial) tidak termasuk yang mensyaratkan nilai minimal tiap-tiap mata pelajaran 4,25 . Sangat terlihat aspek afektif dan psikomotorik siswa cenderung diabaikan.

Ketika konsep, materi, metode, dan evaluasi akhir pendidikan mengalami reduksi dan indoktrinasi untuk kepentingan kekuasaan, maka orientasi pendidikan kian kabur. Di sini, orientasi ilmu sosal lebih bermuara pada menciptakan kepatuhankepatuhan siswa dan guru kepada kurikulum pusat (pemerintah) sehingga siswa hanya menunggu kemandegan daya kritis dan kreativitasnya selama belajar. Meminjam bahasa Abdul Munir Mulkhan (2003), orientasi pendidikan ilmu sosial kita dewasa ini tidak lagi berbasis pada peningkatan aspek afektif, psikomotorik, teologis, dan SARA (HAM), tetapi berubah menjadi industri tenaga kerja dan proyek politik elite penguasa. 
Kedua, terkait dengan persoalan kekerasan simbolis dunia pendidikan. Untuk mengetahui kondisi dan perilaku kekerasan dalam dunia pendidikan, kita perlu mengacu pada proses pembelajaran yang berlangsung selama ini. Menurut Eko Prasetyo (2006) terdapat empat hal yang berkaitan dengan kekerasan dunia pendidikan. Satu, kekerasan kurikulum. Kekerasan lewat kurikulum tampak dari dominasi kekuasaan atas obyek-obyek yang lemah seperti guru dan siswa. Dalam hal ini, penguasa memiliki otoritas dalam menentukan kebijakan atas kurikulum. Kebijakan masa berlaku kurikulum dan masa pembelajaran di tingkat SD, SMP, hingga SMA semua ditentukan dan tersentral harus mengikuti aturan penguasa. Jadi, hampir tak ada ruang gerak bagi guru dan siswa untuk memodifikasi model pembelajaran di sekolah.

Dua, kekerasan metode. Kekerasan metode terjadi ketika metode pembelajaran yang berasal dari kurikulum yang bermasalah diterapkan oleh guru untuk membuat kepatuhan dan ketaatan total pada diri siswa. Teguran, peringatan, hukuman, ancaman, hingga menyampaikan penjelasan materi yang membingungkan siswa adalah bentuk-bentuk dari upaya menciptakan rasa patuh dan loyal siswa kepada guru. Pada tataran ini, guru telah menciptakan homogenitas metode pembelajaran sehingga proses belajar berjalan monoton dan membosankan. Tiga, kekerasan model pembelajaran. Kekerasan ini muncul ketika peran guru sangat dominan dalam menerapkan model pembelajaran sehingga siswa tidak diberi ruang untuk mengajukan alternatif model pembelajaran lainnya. Artinya, penerapan model pengajaran guru yang baku, kaku, dan linier dengan bahan bacaan yang telah ditentukan menempatkan guru sebagai subyek yang superior, sementara siswa sebagai inferior. Dalam model pembelajaran yang homogen ini siswa dianggap sebagai obyek yang statis dan mati dari kreativitas.

Empat, kekerasan orientasi. Ketika pendidikan formal melalui materi pelajaran diarahkan pada pembekalan yang sifatnya teknis, instan, dan menuju satu tujuan yaitu orientasi ekonomi semata (ijazah untuk kerja), maka kekerasan orientasi menemukan tempatnya. Secara faktual kekerasan orientasi ini terjadi dengan arahan guru agar siswa belajar dengan baik dan setelah selesai sekolah dapat diserap oleh industri lapangan kerja. Dengan begitu, secara tidak langsung guru telah menutup peluang dan kreativitas siswa untuk menentukan orientasi pendidikannya. Sekolah dan guru pun terjebak dalam logika rasionalitas instrumental. Rasionalitas instrumental dalam pandangan Fransisco Budi Hardiman (2003) adalah ketika sesuatu dijadikan alat tujuan untuk kepentingan paragmatis berdasarkan kalkulasi strategis (untung-rugi). Di sini, kekerasan orientasi pendidikan yang hanya mengejar nilai ekonomi an sich itu bermuara.

Ragam kekerasan dunia pendidikan seakan-akan telah membuat lingkaran kekerasan atas nama kekuasaan dan hegemoni pengetahuan untuk kepentingan penguasa. Ragam kekerasan tadi jika dinisbatkan pada pandangan Bourdieu akan membentuk kekerasan simbolis yang bertujuan untuk mereproduksi kebudayaan dan mendapatkan legitimasi secara sah melalui pemaksaan yang tersistematis. Secara praksis, dunia pendidikan dengan konsep, materi, metode, model pembelajaran, dan orientasi IPS menunjukkan adanya legitimasi dan 
hegemoni yang meneguhkan relasi kekuasaan itu. Selama sistem pendidikan di negeri ini tidak diubah meski KTSP diberlakukan tanpa adanya political will penguasa untuk menjadikan pendidikan yang berwajah humanis, selamanya pendidikan khususnya "humaniora" akan tersungkur dan mengalami dehumanisasi. Struktur yang menciptakan konsep pendidikan yang homogen, baku, dan kaku, serta serba pasti sehingga menjadikan hubungan antarmanusia seperti hubungan guru dan siswa yang terpisah dan tersubordinasi dengan meminjam istilah Syafii Maarif (Gerbang, 2005), menunjukkan bahwa pendidikan kita benar-benar telah mengalami pendangkalan kemanusiaan. Jadi, sistem pendidikan termasuk sekolah dan guru secara sistematis telah menjadikan heterogenitas dan pluralisme tercerabut dari akar sosiologisnya dari diri siswa.

\section{PENUTUP}

Pendangkalan kemanusiaan dalam pelajaran ilmu-ilmu sosial dari SD hingga SMA nyata terjadi. Hal ini dapat diketahui dari beberapa faktor, yaitu terkait dengan sejarah IPS masa lalu yang kental dengan nuansa politis dan indoktrinasi, penerapan model pembelajaran IPS yang serba kaku, monoton, dan homogen, superioritas guru yang menganggap dirinya sebagai subyek aktif di satu sisi, sementara menempatkan siswa sebagai obyek statis di sisi lainnya, membuka selubung terjadinya kekerasan simbolis dunia pendidikan yang terlanggengkan. Dengan demikian, sistem pendidikan kita benar-benar melegitimasi terjadinya hegemoni dan kuasa pengetahuan atas nama kekuasaan demi kepentingan kekuasaan itu sendiri dari struktur atas (penguasa, elite) ke struktur bawah (institusi, sekolah, guru).
Dalam rangka keluar dari hegemoni dan kuasa pengetahuan yang menyebabkan terjadinya pendangkalan kemanusiaan tersistematis, maka upaya dekonstruksi paradigma pendidikan tradisional yang dehumanis ke paradigma pembelajaran yang humanis adalah suatu keniscayaan. Kurikulum berbasis KTSP yang mulai berlaku 2006-2007 merupakan upaya menuju paradigma pembelajaran yang humanis, karena mampu melibatkan siswa dalam keseluruhan proses pembelajaran yakni aspek kognitif, afektif, dan psikomotorik. Meskipun dalam praksisnya, KTSP disinyalir telah tereduksi oleh kepentingan-kepentingan hegemoni dan kuasa pengetahuan para penguasa tertentu. Hal yang perlu dilakukan adalah mengintensifkan peran politik (political will) para guru dan stake holders yang dapat melahirkan pemikiran-pemikiran kritis dan bernas sehingga menjadi alat bargining position yang kuat dan diperhitungkan. Selain itu, reformasi konsep, materi, metode, dan evaluasi akhir pendidikan (UN) dengan menjalankan fungsi dialektika logis dan argumentatif merupakan suatu keharusan. Dan yang terpenting, diperlukan keberanian guru (sekolah) untuk meruntuhkan hegemoni dan kuasa pengetahuan di bidang pendidikan menjadi kunci utama reformasi. Bangkit dan jayalah dunia pendidikan Indonesia!.

\section{DAFTAR PUSTAKA}

\section{Buku}

Freire, Paulo., Politik Pendidikan, Yogyakarta: Kerja sama REaD dan Pustaka Pelajar, 2002.

Gerbang, Pendidikan Kita Mengalami Pendangkalan Kemanusiaan. 
Yogyakarta: LP3 UMY Edisi 4 Th. V2005, hal. 31.

Hardiman, Fransisco Budi, Kritik Ideologi. Yogyakarta, Buku Baik, 2003.

Jenkins, Richard., Membaca Pikiran Pierre Bourdieu. Yogyakarta, Kreasi Wacana, 2004.

Mulkhan, Abdul Munir, Dari Semar Ke Sufi Kesalehan Multikultural sebagai Solusi Islam. Yogyakarta, Al-Ghiyats, 2003.

Prasetyo, Eko., Orang Miskin Dilarang Sekolah!, Yogyakarta, Resist Book, 2006.

Tilaar, H.A.R., Paradigma Baru Pendidikan Nasional, Jakarta, Rineka Cipta, 2000.

\section{Internet}

Ubaidillah, A, Pendidikan Kewarganegaraan dan Demokrasi Indonesia dalam http:///kompascetak/0401/16/opini/794093.htm [10 Juni 2008] 